https://doi.org/10.38129/Ann.Yur.Ist.2020.4.4.47

УДК 341.21+342.156+321.01(341.211/214)

\title{
ГУННСКИЙ СОЮЗ: \\ ИСТОРИКО-ЮРИДИЧЕСКОЕ ИССЛЕДОВАНИЕ О ПРИНЦИПАХ МЕЖДУНАРОДНОЙ ПРАВОСУБЪЕКТНОСТИ И ЭТНОКУЛЬТУРНОЙ КОМПЛИМЕНТАРНОСТИ В V ВЕКЕ
}

\author{
ВИКТОР МЕЛЬНИК (Киев, Украина) *
}

Методологический экскурс. Поскольку историческая наука посвящена изучению исторического процесса, а исторический процесс является совокупностью жизнедеятельности человеческих союзов (прежде всего социальных групп), то наиболее пристальное внимание историка должно быть сосредоточено вокруг «жизни социальной». У Василия Ключевского (1841-1911) читаем: «Содержанием истории как отдельной науки, специальной отрасли научного знания служит исторический процесс, то есть ход, условия и успехи человеческого общежития или жизнь человечества в её развитии и результатах. Человеческое общежитие - такой же факт мирового бытия, как и жизнь окружающей нас природы, и научное познание этого факта - такая же неустранимая потребность человеческого ума, как и изучение жизни этой природы. Человеческое общежитие выражается в разнообразных людских союзах, которые могут быть названы историческими телами и которые возникают, растут и размножаются, переходят один в другой и, наконец, разрушаются, - словом, рождаются, живут и умирают подобно органическим телам природы. Возникновение, рост и смена этих союзов со всеми условиями и последствиями их жизни и есть то, что мы называем историческим процессом» ${ }^{1}$.

Социальная жизнь, выражающаяся в эволюции человеческого общежития, является сферой общественных наук. Важнейшим элементом общечеловеческой интеракции всегда была и остается политика2 ${ }^{2}$ Вне политики рассматривать исторический процесс бессмысленно, хотя попытки

\footnotetext{
${ }^{1}$ Ключевский В. О. Сочинения: в 9-ти томах. Том 1. Курс русской истории. Ч. 1. / Под ред. В.Л. Янина. М.: Мысль, 1987. С. 34.

${ }^{2}$ Кирилюк Ф. М. Неопатримоніалізм: історія, теорія, практика. К.: «Вадекс», 2014. С. 139-164.
} 
предпринимались неоднократно (в частности, позитивистами и представителями французской историографической школы «Анналов»).

За последнее время, $b$ среде историков политики часто используются различные политологические и юридические подходы ${ }^{3}$. Многие анализируют определенные факты всемирной истории с позиций политологической теории государства (так называемые «этатисты»)4, некоторые смотрят на историю с точки зрения «гражданственности» (сторонники концепции моральноэтического доминирования «гражданского общестьа») 5 .

В рамках цивилизационного направления всемирно-исторических исследований 6 превалируют этнополитические, геополитические или глобальные подходы. На наш взгляд, основная проблема использования различных политолого-юридических подходов в исторической науке состоит в их неспособности объяснить логику прошлого на материале эволюционного развития закономерностей мышления. Этот кризис междисциплинарного соединения истории и политологии касается не только области практического применения традиционной логики как фундаментального анализа мышления7, но и общефилософского понятия о прогрессе человеческих коллективов (по В. О. Ключевскому, «людских союзов») - смысле культуры. В центре любой социальной науки должны находится категории «идентичность» и «сознание». Если мы говорим о политологии, то эти категории превращаются в «политическую идентичность» и «политическое сознание». Если же говорим о рассматриваемых нами юридических вопросах, то речь безусловно идет о

${ }^{3}$ Мельник В. М. Теория симфонии в горизонтальном и вертикальном измерениях как политико-антропологическая черта Византийской истории. // Гілея: науковий вісник. Збірник наукових праць. 2017. Вип. 127 (12). С. 391-392. Мельник В.М. Значение составного лука и гуннской конницы для трансформации военно-политической стратегии Римской империи // Тези доповідей Третьої Міжнародної зброєзнавчої конференщії (12-14 червня 2018 р.). К.: Інститут історії НАН України, 2018. С. 9-10.

${ }^{4}$ Кирилюк Ф. М. Неопатримоніалізм: історія, теорія, практика. К.: «Вадекс», 2014. С. 411-459.

${ }^{5}$ Келиер О. Б. Истоки самоуправления, магистрат и войты в белорусских городах и местечках с магдебургским правом // «Наукові засади об’єктивності і суб'єктності громадянського суспільства» (м. Київ, 24-25 квітня 2017 року) в рамках «Днів науки філософського факультету - 2017». / за заг. ред. проф. Ф. М. Кирилюка. К.: КНУ ім. Т. Шевченка, 2017. С. 14.

6 Риер Я. Г. Локальные цивилизации средневековья: генезис и особенности. Могилев: МГУ им. А.А. Кулешова, 2016. С. 8-16.

${ }^{7}$ Конверский А. Е. Логика традиционная и современная. М.: «Идея-Пресс», 2010. С. 15. 
«правовой идентичности», «правосознании». Но возможен ли грамотный анализ указанных составляющих политико-правовой культуры без полноценного изучения и, что должно следовать за ним, понимания причинно-следственных связей в истории политики? Ответ однозначен: невозможен.

Соответственно, на помощь в нашем исследовании приходит важный элемент теории политики - политическая антропология как учение и метод обществоведческого исследования. Политическая антропология исследует идейные и идеологические особенности развития традиционных форм политического устройства в историческом процессе 8 .

Как писал один из первых теоретиков данной дисциплины Жорж Баландье (1920-2016): «Политическая антропология обеспечивает прорыв границ, присущих партикулярному опыту и отдельным политическим доктринам. Она закладывает фундамент науки о политическом, рассматривая человека в форме homo politicus, ищет качества, общие для всего исторического и географического многообразия политических типов организации» ${ }^{9}$.

Поскольку политическая антропология базируется на принципе «традиционности и/или традиционализма» (то есть, изучения традиции как формы политической репрезентации каждого сообщества в историческом процессе), ее использование во всемирно-исторических штудиях становится желательным и, в связи с развитием теоретического кризиса политологии, своевременным ${ }^{10}$. Принцуип «традиционности», заимствованный из политической антропологии, означает изучение истории политики как набора традиционных политических систем и психологических схем организованности, развивающихся, согласно общей теории социальной (культурной) антропологии, в рамках конкретного географического «месторазвития» («ландиафтта», реже - «иивилизаиии»), под воздействием стабильных естественных факторов 11.

Основа политической антропологии - признание равенства всех культур и цивилизаций, обоснование равноценного вклада каждого этноса (даже

8 Мельник В. М. У полоні інтерпретацій. Політична антропологія між Сходом i Заходом. Монографія. Вінниця: Нова книга, 2020. 280 с.

${ }_{9}^{9}$ Баландъє Ж. Політична антропологія. К.: Альтерпрес, 2002. С. 13.

${ }^{10}$ Мельник В. М. Політична антропологія: що та яким чином вона вивчає? / /Філософія в сучасному науковому та соціально-політичному дискурсах. Матеріали доповідей та виступів Всеукраїнської науково-практичної конференції з міжнародною участю. 19 листопада 2020 р. Вінниця: ВНМУ ім. М. І. Пирогова, 2020. С. 130-133.

${ }^{11}$ Мельник В. М. Нариси 3 теорії соціокультурної антропології. Вінниця: «Вінницька міська друкарня», 2015. С. 288-370. 
небольших племен) в становление «общечеловеческой культуры». Польский антрополог Анджей Менцвель (род. 1940 г.) называет такой подход «антропологическим представлением» (в оригинале «wyobraznia antropologiczna»). Синтезируя многовековые философские и культурологические идеи, Менцвель относит к «антропологическому представлению» тезисы о «наследственности человека $b$ культуре и культуры $b$ человеке» 12 , об «исторической последовательности систем коммуникаиии» ${ }^{13}$ и об «этноиентризме сознания человека»14. Для «антропологического представления» характерно понятие всеобщего равенства людей через их естественное неравенство. «Все равны $b$ своем неравенстве». Соответственно, система человеческих взаимоотношений равенства/неравенства формирует социально-политическую повестку дня. Например, корни важнейшей историкоюридической проблемы неравенства государств растут из семени «антропологического представления» 15.

Из общей темы нашего экскурса становится понятно, что всеобее ощущение равенства в неравенстве может быть объяснено на примере императорской римской и позденантичной гуннской правовых культур. Обе правовые культуры представляли собой сложный и взаимопереплетенный мировоззренческий комплекс. Речь идет, как минимум, о такой системе ментальных взаимоотношений, в условиях которой, римляне сознавали свое культурное превосходство над гуннами, а гунны свое военное превосходство над римлянами ${ }^{16}$. Однако, специфика «антропологического представления», используемая нами в политической антропологии состоит в том, что обе стороны обязательно ощущали именно свое «культурное превосходство». Для того, чтобы понять их взаимоотношения, исследователь (даже будучи юристом-международником или политологом, а не «чистым» историком!) обязан погрузиться в историко-географические, естественно-климатические и психологические условия данного времени (поздней античности и раннего средневековья) и «мыслить оикумену» одновременно по-римски и по-гуннски.

\footnotetext{
12 Менивель А. Антропологічна уява. Есе й нариси. К.: «Юніверс», 2012. С. 5.

13 Там же.

14 Там же. С. 11.

15 Мельник В. М. Византия, германцы и славяне у истоков международной правосубъектности государств: римское юридическое наследие и проблема исторического неравенства возможностей // Аннали юридичної історії. 2017. Т. 1. Вип. 2. С. 59-70.

16 Люттвак Э. Н. Стратегия Византийской империи. М.: Русский фонд содействия науке и образованию, 2016. 664 с.
} 
(Кстати, замечательный методологический указатель по этому поводу содержит синтетическая монография Жака Ле Гоффа (1924-2014)17.

С философских позиций способ реалистического познания особенностей древних правовых культур обосновал Мартин Хайдеггер (1889-1976), написавший: «мышиение греков надо мыслить по-гречески» 18 . С научнопсихологических и культурологических позиций тезис Хайдеггера, творчески разработанный Менцвелем, развивала Маргарет Мид (1901-1978)19.

В частности, М. Мид изучала тихоокеанские островные культуры XX в., основываясь на методе emic-approach. Смысл его лучше всего выражается указанной цитатой Хайдеггера. Задачей метода «является фрормулирование принципов, вероятных для ююбой отдельной культуры, одновременно уделяется внимание тем аспектам миропонимания, которые сами люди считают важными для себя и знакомыми» 20 . Какими же были главные аспекты юридического миропонимания гуннов в позднеантичном мире (де-юре, в римской ойкумене)21? Объяснение этой задачи составляет предмет антропологического изучения юридической истории. В свою очередь, то, какие гуннские традииии были общими для евразийского пространства настолько, что сохранились $b$ качестве культурных паттернов до наших дней, представляет сугубо политологический интерес.

Гунны как политический союз. Ранее мы уже неоднократно замечали: гуннский вопрос сложнее проблемы эволюции любого неримского народа («варваров»). Вторгаясь на земли Причерноморья (375 г. н. э.), гунны были яркой и состоявшейся кочевой цивилизацией: «Быт гуннов зависел от соединения кочевнических и оседлых форм ведения хозяйства. Собственное

17 Ле Гоффр Жак. Рождение Европы. / Серия «Становление Европы». / Пер. с фр. А. И. Поповой. Предисл. А. О. Чубарьяна. СПб: «Александрия», 2014. 398 с.

18 Хайдеггер М. Изречение Анаксимандра. // Хайдеггер М. Разговор на проселочной дороге. Сборник. Пер. с нем. / Под ред. А. Л. Доброхотова. М.: Высшая школа, 1991. C. 39.

${ }_{19}$ Мид М. Культура и мир детства. Избранные произведения. / пер. с англ. и коммент. Ю. А. Асеева; сост. и послеслов. И. С. Кона. М.: Наука, 1988. С. 9.

20 Данилюк I. Етнічна психологія як галузь наукового знання: історико-теоретичний вимір. К.: «Самміт-Книга», 2010. С. 11.

21 Важно, что гунны никогда не мыслили себя антитезой Риму (если использовать расхожий термин Г.-В.-Ф. Гегеля). Гунны всегда нацеливали себя на восприятие романской культуры, принимали федератские правила дипломатической игры и часто действовали именно в публично-правовом поле Рима, как Западного, так и Восточного. 
внутреннее развитие, войны, цивилизационное влияние Китая - все это вместе способствовало созданию первого в истории Центральной Азии государственного формирования» 22.

Как существовал некогда Скифо-сарматский мир, вступавший в противостояние и взаимодействие с античностью 23 , так образовался особый Гуннский мир, наследовавший цивилизационный ареал скифо-сарматских племен, чему способствовал кочевой быт ${ }^{24}$, объединивший местные племена, сохранившиеся в причерноморской степи под владычеством готов ${ }^{25}$.

Первоначальных исторических гуннов среди известных римским хроникам Hunni оставалось предположительно немного ${ }^{26}$. Считается, что гунны (Hunni) пришли с территории Северного Китая. Их многовековой поход сопровождался образованием ряда политических структур 27 . По мнению Льва Гумилева (1912-1992), первое такое образование с тюркским этническим субстратом создано было на китайских землях в III в. до н. э. Во второй половине II в. н. э. гунны занимали уже Волжско-Уральское междуречье, где подчинили угро-финнов, составивших костяк орды. В 370-х гг. гунны выступили против аланов, запустив «горячую фазу» Великого переселения народов. Аланы перекочевали на запад и вторглись в пределы Западной Римской империи ${ }^{28}$. То же случилось и с вестготами ${ }^{29}$. В 390-е гг. гунны обосновались на Паннонской равнине ${ }^{30}$. Началась серия больших походов против германцев, заставившая вандалов и свевов прорвать рейнскую границу 31 декабря 406 г. ${ }^{31}$.

22 Котигорошко В. Г. Верхнє Потисся в давнину. Ужгород: «Карпати», 2008. С. 293.

${ }^{23}$ Мозолевський Б. М. Етнічна географія Скіфії. К.: «Стародавній Світ», 2013. С. 8-22.

${ }_{24}^{24}$ Мурзин В. Ю. Скифская проблема глазами автора. К.: Видавець Олег Філюк, 2014. 120 c.

${ }^{25}$ Об этом см. детали: Мюссе Люсъен. Варварские нашествия на Европу: германский натиск. Пер. с фр. А. П. Саниной. СПб: Евразия, 2008. 400 с.

26 Гумилев Л. Н. Три китайских царства. М.: Алгоритм, 2011. 272 с.

27 Об этих структурах в «долгосрочной» перспективе см.: Гумилељ Л. Н. В поисках вымышленного царства. СПб: Азбука, 2014. 480 с.

${ }_{28}^{2}$ Мюссе Люсъен. Варварские нашествия на Европу: германский натиск. СПб: Евразия, 2008. C. 45.

29 Там же. С. 51.

30 Там же. С. 41.

31 Мельник B. М. Право foedus, правовая коммуникация и политическая дезинтеграция Западной Римской империи. // География в современном мире: 
В 408 г. гунны угрожали восточноримской (византийской) Фракии ${ }^{32}$, а в 415 г. совершили поход в Иллирик. Приближение гуннов сыграло немаловажную роль для отступления вестготов в Италию (401 г.). Король Аларих (382-410) вовремя вывел свой народ на «новый оперативный простор»33, но в 400-х гг. гунны появились на Балканах. Римляне ещё во времена пребывания там вестготов понимали, что гунны представляют грозную силу и могут быть использованы в борьбе с германцами. Большая часть населения неримской Европы уже платила гуннам дань ${ }^{34}$.

Восхождение на западноримский престол малолетнего сына Галлы Плацидии Валентиниана III (425-455) подавало надежды италийской аристократии на восстановление тесной военно-политической связи с Восточной частью Римской империи (Византией). Галла Плацидия была дочерью великого императора Феодосия (379-395) - родной сестрой августов Аркадия Восточного (395-408) и Гонория Западного (395-423), что позволяло политической элите Италии и Галлии рассчитывать на поддержку Константинополя. Несмотря на углубление политических различий между двумя частями единой империи, восточный август Феодосий II (408-450) помогал Галле Плацидии в борьбе с узурпаторами 35 . Восток принимал на себя большинство ранних атак гуннской орды (408-420 гг.). Однако, со временем политическая конъюнктура заставила Равенну (столицу Западной части империи) это забыть.

Первые официальные дипломатические переговоры римлян с гуннами начались по инициативе Западной части Империи. Галла Плацидия решила уничтожить варварские племена Центральной Европы, представлявшие опасность для Запада. Для сохранения власти Валентиниана III (425-455) выгодно было склонить гуннов двинуть основные силы в северо-западном направлении - на германские лесные массивы. Главным переговорщиком с гуннами, соответственно, стал доверенный полководец Плацидии по имени

вековой прогресс и новые приоритеты. Сборник статей XIV Большого географического фестиваля. СПб: Институт наук о Земле СПбГУ, 2018. С. 1013-1016. 32 Мюссе Люсъен. Варварские нашествия на Европу: германский натиск. СПб: Евразия, 2008. C. 42.

33 Там же. С. 51-54.

${ }^{34}$ См. контекст: Melnyk V. M. Political Byzantinism in the Legal History of Franks. Vestnik of Saint Petersburg University. History. 2020. Vol. 65, Issue 1. Pp. 228-232.

35 Эти различия, подчеркиваем, являлись во всех случаях скорее партийнофракционными (политическими), нежели ментально-психологическими (культурными). Восток и Запад являлись двумя частями единой империи. 
Флавий Аэций. Он провел всю свою молодость заложником в гуннской ставке и сумел убедить «ордынцев» вступить в союз с Римом.

Первая «испытательная» кампания для гуннов - участие в подавлении антиимперского выступления вестготов (427 г.). Во время этой акции кочевники дошли дальше, чем во времена нашествия Аттилы (вплоть до современных испанских территорий, пересекли Пиренеи).

Уже в 428 г. гунны разгромили и подчинили себе франков, доставлявших определенные неудобства прирейнской Галлии.

В 430 г. гунны совершили первый поход против бургундов (конечно, санкционированный Западной частью империи). Гуннские вторжения в область бургундов происходили в 430-х гг. Известно о нападении 436 г., санкционированном Равенной. Эти события получили живой отклик в германском эпосе. Достаточно вспомнить Песнь о нибелунгах. В противостоянии с гуннами погиб гех бургундов Гунтиарий. Получается, что западные римляне, имевшие с бургундами законный договор о предоставлении права foedus, то есть, продолжая владеть рейнскими территориями юридически, «натравили» против своих федератов гуннскую орду ${ }^{36}$. Напомним, что племена федератов (федераты - варвары, получившие от императора так называемое право foedus) являлись римскими подданными (хотя и негражданами), добровольно признавшими власть императора, лично зависимыми от его воли.

Победа над бургундами закрепила политический союз Равенны и Гуннского союза. К этому времени гуннским вождем стал Аттила (434-453). Поскольку бургундский поход добавил Аттиле политических баллов, в 439 г. западноримский император Валентиниан III, опираясь на Флавия Аэция, предоставил гуннам право foedus - провинцию Западная Паннония передали Аттиле ${ }^{37}$. Таким образом, Равенна отдала гуннам имперскую провиниию и вступила в публично-правовые отношения с ордой 38 . Этот факт стал исходной точкой для укрепления власти Аттилы. Вполне может быть, что Западная Римская империя надеялась так обезопасить себя от гуннов: постепенно их интегрировать и ассимилировать в римском культурном пространстве.

\footnotetext{
36 Мюссе Люсъен. Варварские нашествия на Европу: германский натиск. СПб: Евразия, 2008. C. 78-83.

37 Мельник В. М. Смена эпох: очерк формирования римско-византийской доктрины международного права (III-VI века). // Аннали юридичної історії. 2018. Т. 2. Вип. 1-2. С. 85-92.

38 Там же.
} 
Необходимо помнить: Западная империя провела с гуннами намного больше времени в союзнических договорных отнотениях, чем в боевых столкновения ${ }^{39}$.

Руководствуясь договором 439 г., Западная часть Римской империи считала гуннов своими федератами, инкорпорированными в имперское правовое поле наравне с вестготами, вандалами и бургундами. С точки зрения Рима гуннское объединение не было государством. Высшим суверенитетом Гуннский союз, по всей видимости, обладал только в глазах самих гуннских воителей (выражаясь, согласно субъективистскому универсализму методологии етіс-арproach).

Следуем дальше, согласно хронологии. Так называемое «Великое нашествие гуннов на Ebpony» началось в 451 г.40. Гуннская конница двигалась вдоль Дуная и, соединившись с германцами, форсировала Рейн возле Майнца во второй половине марта ${ }^{41}$. Первой под серьезные гуннские удары попала провинция Бельгия. Археологи предполагают, что большая часть ее римского населения была уничтожена. Именно Бельгию историки имеют в виду, когда говорят о пагубных и ужасных для мирного населения последствиях гуннского нашествия. Вместе с гуннами в Бельгию переправилась часть франков, которые спустя тридцать лет сделали эту провинцию центром Франкского королевства, существовавшего под эгидой династий Меровингов и Каролингов с 481 по 843 гг.

7 апреля 451 г. гунны разрушили город Мец, а уже к началу июня Аттила встретился с аланской конницей под стенами Орлеана. Сражения гуннов и аланов на галльской территории Западной Римской империи должны занять подобающее место в общей исторической характеристике Великого переселения народов. Позволительно считать, что именно ожесточенное сопротивление федератов-аланов позволило Флавию Аэцию выиграть время для мобилизации италийской полевой армии. В аланско-гуннском столкновении надо видеть продолжение старого конфликта между «Тураном» и «Ираном». Ведь в 375 г., прежде чем вступить в причерноморскую степь, гунны завоевали земли кочевников-аланов, заставив их искать спасения на западе Европы!

${ }^{39}$ Мюссе Люсъен. Варварские нашествия на Европу: германский натиск. СПб: Евразия, 2008. C. 42.

40 Ермолова И. Е. Римляне и гунны. / / Цивилизация и варварство. 2014. №3. С. 215-221. ${ }^{41}$ Мюссе Люсъен. Варварские нашествия на Европу: германский натиск. СПб: Евразия, 2008. C. $44-45$. 
Бои Аттилы против аланов вокруг Орлеана позволили Аэцию договориться с вестготами о помощи ${ }^{42} .20$ июня 451 г. армии гуннов и римлян/Вестготов встретились на Каталаунских полях. «Гунны» состояли преимущественно из германцев (остготов, гепидов, герулов, скиров, ругов, франков, алеманов), но, безусловно, включали славян и сарматов. «Римляне» состояли из федератоввестготов, галльских ополченцев, бургундов, франков, ираноязычных аланов. Исход был нейтральным. Аттила отступил в Паннонию, откуда совершил вторжение в Италию. В 452 г. Аттила удовлетворил своих подчиненных разграблением Фриули, Аквилеи, Падуи, Мантуи, Виченцы, Вероны, Брешии, Бергамо. Остановить полное уничтожение Италии удалось только дипломатическим путем ${ }^{43}$.

Во-первых, состоялась личная встреча Папы Римского Льва Великого с Аттилой (на реке Минцио). Встреча подчеркнула признание Западным Римом равного статуса Аттилы. Прошли первые в истории личные дипломатические переговоры римского первосвященника с неримским правителем.

Во-вторых, западные римляне, в течение 20 лет натравливавшие гуннов на восточноримские Балканы ${ }^{44}$, вспомнили о юридически едином государстве Востока и Запада, отправив посольство в Константинополь. Восточноримский император Маркиан (450-457) понимая, что во время отсутствия Аттилы, можно нанести сокрушительный удар по семьям и жилищам гуннов, атаковал Паннонию ${ }^{45}$. Аттила устремился на Дунай, где скоро умер. С облегчением римляне смогли вздохнуть только в 454 г., когда наследники Аттилы (сыновья Эрнак, Эллак и Денгизик), направляемые восточноримской дипломатией, развязали гражданскую войну, похоронив в ходе ее, не только друг друга, но и возможность дальнейшей политической трансформации гуннского конфедеративного объединения (союза).

Сущность Гуннского союза. Даже приблизительный очерк гуннской политико-правовой истории, как видим, свидетельствует: во всей классической и современной историографии гуннского нашествия, зеркально отражающей

42 Там же. С. 46-47.

43 Там же. С. 45-46.

44 Это объясняется, прежде всего, политическими интригами и межфракционной борьбой внутри римского политического класса, но не свидетельствует о каких-либо глубоких ментальных расхождениях между Восточной и Западной частями Римской империи.

45 Детали см.: Хизер Питер. Восстановление Римской империи. Реформаторы Церкви и претенденты на власть. М.: Центрполиграф, 2015. 575 с. 
основные события евразийской истории IV-V вв., существует очень много фактологических пробелов. Учитывая вполне понятное отсутствие достаточной базы юридических документов, мы попробуем заполнить эти пробелы, используя политико-антропологическую методологию, в т. ч. amicapproach - составной метод «антропологического представления», анализирующий любую конкретную ситуацию с позиций погружения в мировоззрение и временно-пространственную структуру исследуемого сообщества.

Странно, но западноримские элиты вместо того, чтобы объединить усилия Запада и Востока для отпора вторжению, относились нейтрально к набегам Аттилы на византийские (восточноримские) территории. Существует мнение, что западные римляне специально провоцировали такие набеги. Во всяком случае, Западная Римская империя своей политической раздробленностью многократно усилила эффект событий 451-452 гг. Получается, что длительное время (говоря грубо - с 376 по 451 гг.) вся великая Римская империя (от Гибралтара до Сирии) не предпринимала попыток уничтожить врага на подступах. Ведь она могла не только уничтожить силу гуннов, предотвратив появление Аттилы заранее, но и ослабить в войне племена варваровфедератов. Можно предположить, что федераты до последнего отказывались воевать против гуннов (так оно и было, поскольку все варвары-федераты пришли ранее на земли Рима с целью поиска спасения от гуннов). Но после первой большой победы, федераты, безусловно, присоединились бы к римским регулярным войскам. Западная часть империи, следовательно, получала шанс спастись. На практике случилось иначе. Западноримские политические элиты затеяли большую дипломатическую игру, надеясь ослабить абсолютно всех и, в первую очередь, Восточную часть империи, репрезентовавшую конкурирующие кланы политической элиты ${ }^{46}$. Гунны получили в 439 г. foedus на Западную Паннонию из рук законного императора Валентиниана. Их отношения с Западной Римской империей являлись союзническими. Официальная Равенна использовала гуннов в военных кампаниях против франков, вестготов и бургундов. Благодаря свирепости гуннских набегов Рим удерживал иентрально-германские племена от дальнейшей миграции в Средиземноморье свыше двадияати лет подряд! «Гунны оставались друзьями и союзниками Рима или отдельных римлян куда дольше, чем «бичом

\footnotetext{
46 В этой конкуренции и состояло фундаментальное противоречие между римскими «Западом» и «Востоком».
} 
Божьим», если прибегнуть к одному слишком высокопарному эпитету», считал Люсьен Мюссе 47.

Развивая политико-антропологический анализ внутреннего наполнения гуннско-римских взаимоотношений, выдвигаем следующие программные тезисы:

1) Гуннский конфедеративный союз являлся политическим объединением, признанным де-факто Равенной в 439 г. (предоставлением foedus на Западную Паннонию) и де-юре со стороны Константинополя в 449 г. (посольской миссией Приска Панийского);

2) Юридическое признание со стороны Римской империи обозначало формальное причисление римскими политическими элитами Гуннского союза к отдельной цивилизации (согласно установившимся обычаям, римляне не могли признавать государственность варварских народов ${ }^{48}$;;

3) Гуннское политическое объединение (союз) являлось продолжателем традиций Скифо-сарматского устройства, предполагавшего синтез земледельческой и кочевой жизни ${ }^{49}$. Пребывание на грани леса и степи составляет облик признанной официальным Римом, хоть и ненадолго, «равноправной» Гуннской цивилизации;

4) Культурная динамика социально-экономической интеграции внутри подконтрольного гуннам евразийского пространства детерминировалась условиями исторического развития предшественников (скифов, сарматов, аланов - базис утверждения смотрите в цитированной выше работе Ле

47 Мюссе Люсьен. Варварские нашествия на Европу: германский натиск. СПб: Евразия, 2008. C. 42.

48 Как мы неоднократно отмечали, Императорский Рим/Константинополь считал равноправными (т. е. «правосубъектными») государствами только равноценные политико-правовые объединения (достигшие, по его мнению, цивилизационного уровня). Имеем в виду Китай, Индию, Персию. Признание императором Феодосием II Законодателем (408-450) в 449 г. Аттилы и его ставки через посольство Приска Панийского обозначало причисление Гуннского союза к вышеперечисленному списку государств. Впрочем, уже в 453 г. Аттила умер и победы следующего восточноримского императора Маркиана (450-457) «обнулили» правовую акцию посольства Приска. См. детали: Мельник В. М. Смена эпох: очерк формирования римско-византийской доктрины международного права (III-VI века). // Аннали юридичної історії. 2018. Т. 2. Вип. 1-2. С. 63-108.

49 Петрушенко О. Ф. Сарматський концептуалізм у картографії і літературі. / / Аннали юридичної історії. 2017. Т. 1. Вип. 1. С. 154-159. 
Гоффа50). Гуннское объединение как военно-политический союз независимых племен, двигалось исключительно экономическими интересами материальным обогащением за счет соседей и контролем над торговыми путями по линии Пекин-Ктесифон-Константинополь-Равенна 51.

5) «Пробель» гуннской политико-правовой истории, в силу дефицита источников, могут быть объяснены только путем исследования взаимоотношений с оседлыми («государственными») цивилизациями на материале сравнения ментальности кочевников и земледельцев ${ }^{52}$. Нам интересен лишь один аспект такого взаимодействия (гуннско-римский). Однако, от степени изученности данного одного аспекта зависит успех разработки всей обобщенной модели динамики культурного развития позднеантичного евразийского мира. Опыт изучения гуннско-римских взаимоотношений вполне возможно экстраполировать на китайский и персидский контексты эволюции хуннов/гуннов.

У Л. Н. Гумилева встречаем утверждение: «Зная причины, нетрудно рассчитать их следствия, а зная следствия, обратным ходом мысли можно восстановить причины их породивиие. Поэтому чем больше мы расширим нашу цель 8 пространстве и времени, тем легче мы $\boldsymbol{b}$ нее попадем» 53 . Его мысль, как нельзя кстати, подходит для исторических обобщений в области истории международной правосубъектности. Надо смотреть на гуннскую проблему глобально - как с точки зрения мировой политической географии, так и с точки зрения локальной экономико-юридической практики ${ }^{54}$. Появление гуннов упрочило положение разрозненных германских, славянских, кочевых племен на Восточноевропейской равнине 55 . Они обрели некую политическую субъектность, ставшую в дальнейшем целью взаимной культурной интеграции народов позднеантичного Евразийского пространства 56.

50 Ле Гофф Жак. Рождение Европы. Пер. с фр. А. И. Поповой. Предисл. А. О. Чубарьяна. СПб: «Александрия», 2014. С. 39-43.

51 Люттвак Э. Н. Стратегия Византийской империи. М.: Русский фонд содействия науке и образованию, 2016. С. 65.

52 Гумилев Л. Н. Древняя Русь и Великая Степь. М.: Айрис-пресс, 2011. С. 7-25.

53 Гумилељ Л. Н. В поисках вымышленного царства. СПб: Азбука, 2014. С. 198.

54 Лютmвак Э. Н. Стратегия Византийской империи. М.: Русский фонд содействия науке и образованию, 2016. 664 с. Хизер Питер. Восстановление Римской империи. Реформаторы Церкви и претенденты на власть. М.: Центрполиграф, 2015. 575 с.

55 Лютmвак Э. Н. Стратегия Византийской империи. М.: Русский фонд содействия науке и образованию, 2016. С. 34.

56 Вернадский Г. Начертание русской истории. М.: Алгоритм, 2008. 336 с. 
Впрочем, здесь мы справедливо и закономерно ступаем на тропу культурной детерминации политико-правовых процессов. Почему субъектность вообще должна считаться цуелью? Как минимум потому, что обладание ею предоставляло особые права на приобретение материальной собственности (получение дани/денежного вознаграждения со стороны императора). Обретение и упрочение субъектности всегда осуществлялось военным путем. В те времена война была эффективным способом изъятия/рецепции благ и заодно фактором демографической стабилизации ${ }^{57}$. Исходя из этого, используя т. н. политико-антропологическую методологию 58 и соответствующий ей «панорамный метод» Л. Н. Гумилева ${ }^{59}$, можно предположить, что гуннская война против Запада (как римского, так и варварского) - тактический способ интеграции. Соседство гуннов с ведущими цивилизациями мира (Персия, западные и восточные римские земли) представляло стратегический способ интеграции. Гунны желали приобщится к благам городских и земледельческих цивилизаций, получить статус транзитера между отдаленными цивилизованными государствами. Для этого гуннам надо было самим цивилизоваться, принять римский/персидский/китайский образ жизни и мыслей, заимствовать мироощущение. В конце-концов, после серии поражений 452-454 гг. многие гуннские офицеры, командиры и смышленные ордынцы перешли на римскую службу. Личный секретарь Аттилы Флавий Орест даже сделал сногсшибательную чиновничью карьеру в Западной части Римской империи, где сумел ненадолго усадить на императорский трон своего сына Ромула Августула (475-476). Таким образом, благодаря гуннской склонности быстро адаптироваться, евразийская культурная интеграция приобрела пограничный «синтетический» («всеперемалывающий») характер.

Главным белым пятном «гуннского нашествия» на Римскую империю (речь о «Западном походе» 451-452 гг.) представляется союзнический формат взаимодействия между гуннами и римлянами в 439-450 гг. 60.

В 449 г. Аттила принял в своей ставке посольство восточноримского императора Феодосия II Законодателя (408-450) под руководством Приска

\footnotetext{
57 Ле Гофф Жак. Рождение Европы. Пер. с фр. А. И. Поповой. Предисл. А. О. Чубарьяна. СПб: «Александрия», 2014. С. 28.

58 Мельник В. М. У полоні інтерпретацій. Політична антропологія між Сходом i Заходом. Монографія. Вінниця: Нова книга, 2020. 280 с.

${ }^{59}$ Гумилев Л. Н. В поисках вымышленного царства. СПб: Азбука, 2014. 480 с.

60 Мюссе Люсъен. Варварские нашествия на Европу: германский натиск. СПб: Евразия, 2008. C. 42.
} 
Панийского, труд которого до сих пор является главным письменным источником о гуннах 61 . Посол Приск свидетельствует о двух фактах. Первый существование высокоорганизованной политической структуры внутри гуннского общества 62 . Второй - полиэтнический статус этого общества63. Гунны являли собою настолько пестрый конгломерат многочисленных народов и социальных групп, что по иивилизационному значению и географическому охвату, составляли реальную конкуренцию Римскому миру.

Кочевники-гунны контролировали славян, германцев, кавказских и причерноморских иранцев, угро-финов. Основу гуннской армии представляли племена германцев-остготов. Невозможно оставить без внимания также славянский элемент в политической организации гуннов ${ }^{64}$.

Во-первых, славяне составляли основную часть налогооблагаемого гуннами населения.

Во-вторых, славяне ранее, до гуннского вторжения на Восточноевропейскую равнину (375 г.), подчинялись готам и, соответственно, были инкорпорированы в остготскую политическую элиту 65 .

Соответственно, политическое и военное значение славян для Гуннского союза не могло быть меньше иранского или тюркского. Это вопрос арифметики. Славянский элемент спокойно подавлял одной лишь численностью тюркско-иранские племена востока Европы. В составе Гуннского союза определенное место заняло и латиноязычное население захваченных римских провинций (Дакия, Паннония). Упомянутый выше Орест, отец предпоследнего западноримского императора Ромула Августула (475-476), происходил именно из Западной Паннонии.

Изложенные факты свидетельствуют о социокультурной новизне римсковарварских отношений в «гуннское время». Стандартная форма поведения римлян относительно варваров-германцев или варваров-туранцев, испробованная в течение многовековой греко-римской истории (античный период), больше не действовала на Восточноевропейской равнине. В 449 г.

61 Лютmвак Э. Н. Стратегия Византийской империи. М.: Русский фонд содействия науке и образованию, 2016. С. 67.

62 Там же. С. 64-79.

63 Там же. С. 33-35.

${ }^{64}$ Кіндратенко А. М. Коментар до дискусії між Д. Іловайським та В. Васильєвським 3 питання етнічної належності гунів IV-V століть. Харків: Просвіта, 2004. 32 с.

65 Козак Д. Н. Гунны. Николаев: «Возможности Киммерии», 1997. 24 с. Кіндратенко А. М. Гуни та їхня мова. Харків, 2006. 44 с. 
восточные римляне вынужденно признали государственность гуннов ${ }^{66}$. В этом не может быть сомнений, поскольку посольство Приска 449 г., отправлялось к Аттиле восточноримским императором Феодосием II (408-450) как к равному правителю 67. Игнорировать символизм этого посольства нельзя 68. В то время политическая символика играла куда более важную роль, нежели даже практические формы осуществления политической борьбы! Гуннское конфедеративное объединение (союз) явилось первым, признанным равноправным (m. е. «правосубъектным») со стороны римских императоров, варварским государством. (Впрочем, интерес данного феномена подкрепляется также и тем, что в дальнейшем римские/византийские императоры больше никогда не признавали равноправия «варварских стран» вплоть до 1373 г., когда загнанный в угол мусульманами император Иоанн V Палеолог (1354-1391) признал Османский бейлик «равным» и даже «более значимым»).

Все признаваемые равными Риму государственные образования являлись в то же время и цивилизационными объединениями (Сасанидский Иран, Кушанская Индия, Китай), основывавшимися на принципе этнокультурной комплиментарности. Персия, Китай и частично Индия в IV-V вв. были единственными государствами, которые Рим признавал «полноценными» и с которыми Рим поддерживал правовые межгосударственные отношения 69 . Предки

66 Признание восточными римлянами, в соответствии с наличием единого публичноправового пространства Империи, автоматически означало признание и западными римлянами. Так что вполне правильно будет говорить просто о «римском признании Гуннского союза».

67 Люттвак Э. Н. Стратегия Византийской империи. М.: Русский фонд содействия науке и образованию, 2016. С. 66-67.

68 Как известно, для юриспруденции именно символы играют первостепенную роль. Поэтому мы ничуть не преувеличим, если назовем юриспруденцию наукой и практикой, прежде всего, семиотической.

${ }^{69}$ См., к примеру, контекст отношений Рима/Византии с Китаем, развивашихся на фоне становления и укрупнения Великого Шелкового пути: Конрад Н. И. Глава I. Развитие феодальных отношений в Китае (III-VIII вв.). / / Всемирная история в десяти томах. Том III. М.: Государственное издательство политической литературы, 1957. С. 39. Пигулевская Н. В. Византийская дипломатия и торговля шелком. // Византийский временник. 1947. Т. 1 (XXVI). С. 184-214. Лубо-Лесниченко Е. И. Китай на Шелковом пути. Шёлк и внешние связи древнего и раннесредневекового Китая М.: Восточная литература, 1994. 326 с. Баринова Е. Б. Взаимодействие Китая с западными территориями в древности и средневековье. // Диалог со временем. 2012. Вып. 40. С. 
гуннов хорошо ознакомились с городской культурой и достижениями древних китайцев и персов. Это делало их кочевнический образ жизни сознательным выбором идентичности 70. Понимая, что участие в политическом процессе оседлых народов, имеющих тысячелетний опыт управления, очень рискованно для их власти, гуннские вожди предприняли смелый шаг по объединению кочевников различного этнического происхождения. Своими контактами с иранцами и северокитайским миром, гунны добавили «культурного давления» на Восточноевропейской равнине ${ }^{71}$. Археологи замечают, что пространство, на котором сегодня находятся Украина, Молдавия, Румыния, заметно оживилось. Значительно увеличился приток золотых имперских монет и утонченных ювелирных изделий. Об этом свидетельствуют захоронения. Одно только количество золота, потраченного на сопровождение усопших вождей в мир иной, могло бы стать бюджетом победной войны варварского мира против Римской империи.

Гунны использовали разные средства для подчинения племен своей власти. И власть эта, в абсолютном большинстве случаев, представляла номинальную величинуㄹ․ К примеру, вожди германцев-герулов признавали Аттилу своим верховным правителем, обязывались платить гуннским сборщикам налогов дань и регулярно посылать подарки. Взамен, Аттила давал слово защищать их от посягательств соседних племен. Ради исправного получения налогов, Аттила обязывался чтить самостоятельность племен, заключавшуюся в праве военных походов и набегов на римскую территорию. Все средства считались хорошими для заработка, идущего не только на выплату дани, но и на обеспечение своих семей необходимыми для жизни экономическими излишками. В границах современных Венгрии, Румынии, Молдавии, Сербии и

94-117. Омашева Ж., Танабаева А. Культурные и исторические связи стран Шелкового пути. // Alatoo Academic Studies. 2017. № 3. С. 351-355.

70 В признании и продвижении данного тезиса парадоксально сходятся усилия двоих кардинально противоположных по своим мировоззренческо-идеологическим установкам ученых: Гумилељ Л. Н. В поисках вымышленного царства. СПб: Азбука, 2014. 480 c. et Хизер Питер. Восстановление Римской империи. Реформаторы Церкви и претенденты на власть. М.: Центрполиграф, 2015. 575 с.

71 О значении категории «культурное давление» см. две разные, но весьма методологически важные сводные работы: Ключевский В. О. Сочинения: в 9-ти томах. Том 1. Курс русской истории. Ч. 1. / Под ред. В.Л. Янина. М.: Мысль, 1987. 430 с. Вернадский Г. Начертание русской истории. М.: Алгоритм, 2008. 336 с.

72 Люттвак Э. Н. Стратегия Византийской империи. М.: Русский фонд содействия науке и образованию, 2016. С. 66. 
Украины археология подтверждает возрастание темпа и повышение уровня экономического обогащения ${ }^{73}$. На этих данных базируется утверждение, что Днепро-Дунайское междуречье было ядром гуннской конфедерации. Богатства элиты свидетельствуют не только о постоянных набегах на близлежащие земли Западной/Восточной Римской империй. Они говорят также о согласии племенных масс хоронить эти сокровища вместе с вождями, что приводит к мысли о дотоле небывалом уровне присвоения богатств. Попросту Аттила создавал для своих подчиненных возможности самостоятельного заработка и гарантировал безопасность. Гуннам удалось сплотить варваров Европы путем иентрализованного перераспределения ресурсов. В итоге, Римская империя де-юре (посольством Приска 449 г.) приравняла гуннов к отдельной изивилизации, признав их равенство и правосубъектность.

Классик историографии Георгий Вернадский (1887-1973) называл «Гуннскую империю» евразийским объединением, представившим миру формат континентального общежития ${ }^{74}$. Для Вернадского «Гуннский союз - первая модель» евразийской империи. По Г. Вернадскому и Л. Гумилеву: континентальная евразийская история развивается цикличным путем - корни любой евразийской государственности необходимо искать в структурах и объединениях античного времени (скифо-сарматском, готском, гуннском, аварском союзах). Если предположить, что это действительно возможно, то остается только гадать, почему современные политические аналитики не обращают пристального внимания на формы и способы экономико-политико-правовои репрезентации античных и средневековых культурных процессов? Ведь изучение таких процессов может привести к очень рациональным выводам. Многие события $\mathrm{V}$ в. легко ассоциируются с актуальной повесткой дня. Речь идет, в частности, о проблематике «смены эпох», «трансформации времен»75. Остается отметить лишь то, что интеграционные процессы никогда не теряли своей актуальности для полиэтнического населения Евразии - нашего общего месторазвития. Согласно Г. Вернадскому, своим падением «Гуннская империя» лишь подготовила почву и «место для очередного образования других соединенных империй» 76.

73 Хизер Питер. Восстановление Римской империи. Реформаторы Церкви и претенденты на власть. М.: Центрполиграф, 2015. 575 с.

74 Вернадский Г. Начертание русской истории. М.: Алгоритм, 2008. С. 32-33.

75 Браччіні T. Пізньоантична Італія і так званий кінець античного світу. // Історія європейської цивілізації. Рим. / За ред. У. Еко. Харків: Фоліо, 2017. С. 212.

76 Вернадский Г. Там же. 
Подытожывая наш скромный теоретический экскурс, должны заметить: система политической интеграции может быть определена в качестве традиционной формы социального мировоззрения (и, соответственно, менталитета) народов Евразийского пространства, некогда объединенных «Гуннским союзом». Разрабатывая историческую повестку евразийской/европейской и любой другой интеграции, политическим и правовым экспертам необходимо использовать весь имеющийся ресурс психологических архетипов/стереотипов/паттернов исторической памяти, включая осознанную/неосознанную апеляцию к изивилизационному единству, восходящему своими корнями к эпохам поздней античности или раннего средневековья.

Так или иначе, применение политико-антропологического подхода к отдельным контекстам всемирной юридической истории оправданно, поскольку позволяет проследить «генетическую» связь между политическими традициями древней и новейшей истории, а также составить прогноз на будущее. Политические традиции - мощный двигатель прогресса, так как их консервация позволяет удерживать социальный баланс между человеческими пороками и добродетелью. Удачно по этому поводу выразился Жак Ле Гофф: «Прочлое не должно связывать руки настоящему, но может помочь ему развиваться, сохраняя верность традициям, и создавать новое, продвигаясь вперед по пути прогресса»77.

Гуннский конфедеративный союз еще только ждет своего историкополитологического описания, но применение «антропологического представления» посредством етіс-подхода делает получение политикоправовых данных из «обрывков» позднеантичной ментальности вполне реальным. Это лишь небольшой пример практического использования антропологического подхода на конкретно-историческом материале. Прав был юрист Константин Победоносцев (1827-1907), единожды написавший: «наука о человеке способна выполнить связующую функцию для всей совокупности человеческих знаний»78. Впрочем, погружаясь в политическую антропологию, как способ изучения традиций политической семиотизации истории

77 Ле Гофф Жак. Рождение Европы. Пер. с фр. А. И. Поповой. Предисл. А. О. Чубарьяна. СПб: «Александрия», 2014. С. 9.

78 ПобедоносиеВ К. П. Государство и Церковь. / Сост., предисл., коммент. О. А. Суржик. М., 2011. T. 1. C. 29. 
права, советуем не забывать фразу психолога Эриха Фромма: «Задачей является понять учение, изучая людей, а не людей, изучая учение»79.

PhD in Political Science Viktor Melnyk (Kyiv, Ukraine)

Hunnic Union: Historical and Legal Research on the Principles of the International Legal Personality and Ethnocultural Complementarity in the $5^{\text {th }}$ century Europe

The article focuses on the origins of Eurasian political thinking and describes the first confederative prototype of Eurasian political and legal integration, which have spread in the territories of Central and Eastern Europe. In the center of the narrative is the history of the European steppe and forest-steppe borderland of the V century. This topic is considered by the author as a specific scientific problem of political anthropology. According to the author's opinion, political anthropology is a political science discipline exploring the ideological and psychological aspects of the genetic evolution of traditional forms of political structure and consciousness in the historical process. The period of Hun domination on the East European Plain is presented by the author as the time of active political and legal contacts between Rome and the barbarians. The article attaches great political importance to the provision of lex foedus to the Huns in 439. Using a large array of classical anthropological and historical literature, as well as a critical comparison of primary sources, the author offers his own definition of the Hunnic Union, considering it as a military-political confederation. The author's position departs from the "Eurasian imperial trend" in order to substantiate the model of cultural integration within the framework of more powerful political, economical and geographical concepts "Land Civilization" (Rome) and "Nomadic Barbarianism" (Huns).

Key words: Huns, Hunnic Tribal Confederation, Foederati, Lex Foedus, Eastern Roman Empire (Byzantium), Western Roman Empire, Political Anthropology, Political Tradition.

\footnotetext{
79 Фромм Эрих. Догмат о Христе и другие эссе по религии, психологии и культуре. // Фромм Э. Вы будете как боги: сборник; пер. с англ. М.: АСТ, 2013. С. 25-26.
} 
кандидат политических наук Виктор Мельник (Киев, Украина)

Гуннский союз: историко-юридическое исследование о принципах международной правосубъектности и этнокультурной комплиментарности в V веке

В статье исследуется первый конфедеративный прототип евразийской политико-правовой интеграции, развивавшийся на территориях ЦентральноВосточной Европы. В центре внимания находится юридическая история европейского степного и лесостепного пространства V в., рассмотренная автором в качестве специфической проблемы политической антропологии. При этом, политическая антропология понимается как направление, что исследует идейные и идеологические особенности развития традиционных форм политического устройства в историческом процессе. Период владычества гуннов на Восточноевропейской равнине представлен автором как время активных политических и юридических контактов между Римом и варварами. Особое внимание уделено международно-правовому значению предоставления официальной Равенной lex foedus гуннам под руководством Аттилы в 439 г. Используя большой массив классической антропологической и исторической литературы, а также критическое сравнение первоисточников, автор предлагает собственную дефиницию Гуннского союза, считая его военно-политической конфедерацией. В то же время, авторская позиция заключается в отходе от «евразийского имперского тренда», с целью обоснования модели культурной интеграции в рамках более мощных экономико-географических систем - «Земледелие-Цивилизация» (Рим) и «Скотоводство-Варварство» (Гунны).

Ключевые слова: гунны, Гуннский союз, федераты, право foedus, Восточная Римская империя (Византия), Западная Римская империя, политическая антропология, политические традиции.

кандидат політичних наук Віктор Мельник (Київ, Україна)

Гунський союз: історико-юридичне дослідження принципів міжнародної правосуб'єктності і етнокультурної компліментарності в V столітті

У статті досліджується перший конфедеративний прототип євразійської політико-правової інтеграції, що розвивався на територіях Центрально-Східної Європи. В центрі уваги знаходиться юридична історія європейського степового і лісостепового простору V ст., що розглядається автором в якості специфічної проблеми політичної антропології. При цьому, політична антропологія 
розуміється як напрям, що досліджує ідейні та ідеологічні особливості розвитку традиційних форм політичного устрою в історичному процесі. Період панування гунів на Східноєвропейській рівнині представлений автором як час активних політичних і юридичних контактів між Римом i варварами. Особливу увагу приділено міжнародно-правовому значенню надання офіційною Равенною lex foedus гунам під керівництвом Аттіли в 439 р. Використовуючи великий масив класичної антропологічної та історичної літератури, а також критичне порівняння першоджерел, автор пропонує власну дефініцію Гунського союзу, вважаючи його військово-політичною конфедерацією. У той же час, авторська позиція полягає у відході від «євразійського імперського тренда», з метою обгрунтування моделі культурної інтеграції в рамках більш потужних економіко-географічних систем «Землеробство-Цивілізація» (Рим) і «Скотарство-Варварство» (Гуни).

Ключові слова: гуни, Гунський союз, федерати, право foedus, Східна Римська імперія (Візантія), Західна Римська імперія, політична антропологія, політичні традиції.

* Мельник Виктор Мирославович - кандидат политических наук, лауреат премии Ars Translationis им. Н. Лукаша, ассистент кафедры политологии философского факультета Киевского национального университета имени Тараса Шевченко, преподаватель кафедры философии и общественных наук Винницкого национального медицинского университета им. Н. И. Пирогова, главный редактор научного журнала «Анналы юридической истории».

E-mail: melnyk1996ethnology@gmail.com. 